informative Dessaulles and Riel papers to visually appealing scrapbooks, cards and even a milkbottle top collection.

9. Eclectic Tastes: Fine and Decorative Arts from the McCord, May 9, 1992 -

Curator Responsible: Conrad Graham, Curator of Decorative Arts; Contributing Authors: Sarah Ivory, Concordia University; Robert Derome, Université du Québec à Montréal.

Highlighting the nineteenth century, where the McCord holdings of paintings and decorative arts are strong, this exhibition and accompanying catalogue feature both secular and religious silver, furniture, ceramics, glass and wood sculpture. Sometimes important for their documentary value, sometimes for their inherent art-historical value, the artifacts on view underline the duality of the McCord's collecting mandate.

10. Form and Fashion: Nineteenth-century Feminine Dress, May 9, 1992 - January 15, 1993 Curator Responsible: Jacqueline Beaudoin-Ross, Curator of Costume and Textiles.

The form in the evolution of nineteenth-century costume is emphasized in this exhibition and accompanying catalogue. The selection of costumes from the McCord's extensive collection demonstrates that not only are styles in dress revised throughout history, but also that particular elements in attire re-appear again and again. For the first time, photographs from the McCord's Notman Photographic Archives will be used not only to date the costumes but also to demonstrate the evolution of the form. The dissemination of European fashion plates in Montreal is traced to show the extent to which Montreal was a "fashionable venue."

\title{
Breaking the Silence and Bridging the Gap: Documenting Personal Memories of the Holocaust
}

\author{
by Yehudi Lindeman, Associate Professor of English, McGill University
}

...I never thought that I would be able to sit here and talk about these
things. I never had the courage to do it. And then I saw other people com-
ing out... And then, a few times, I heard people say, about people like
me, you are actually an endangered species, because after you are done
there will be nobody else, there will be no one else left to tell the real story.
And my children really wanted me to do it. And maybe because it is fifty
years now, $1939-1989$, I feel that everything is coming full circle, that I
have to do it, that maybe my time is running out.
Renata Skotnicka-Zajdman, in the McGill studio, June 1989.

Renata Skotnicka-Zajdman is one of the many survivors of the Holocaust now in Montreal. Living in increasing fear with "Aryan papers," she managed to survive World War II as a 13 to 18 year old, dodging selections by hiding in cellars and safe-houses, and burrowing her way in and out of the ghettos of Bialystok and of Warsaw, where she witnessed the ghetto uprising. There are thousands of other survivors in the Montreal area.

In June, 1989, Renata was among the first survivors of the Holocaust to be interviewed by "Living Testimonies," McGill University's Video Archive. The Archive's goal is to record on studio-quality video-tape, eye-witness accounts of the Holocaust. Though the focus is on survivors, witness testimony by liberators and rescuers is also included.' 


\section{Notes and Comments}

The need to combine the theoretically grounded ancient Hebrew injunction of zakbor with the practical reality of assisting in the process of petacb (the vulnerable state of opening up) made this a very challenging project. While showing with touching and often painful frankness what precisely happened to an ordinary person caught in the wheels of an extraordinary time, each video document also presents images that provide a powerful counter-argument to the movement of Holocaust denial and historical revisionism. Thus every interview, ideally, constitutes a tremendous resource that has the power to change minds and challenge the perpetuation of anti-semitism and racism, nationally and world-wide. If the project's strength is in any sense weakened, it may be in the realization that with each passing year the survivors are diminishing in number. This is the sentiment that Renata speaks of in the above passage when she refers to people like herself as an "endangered species" whose "time may be running out." But the need to tell the story to the world is also motivated by a personal need of unburdening oneself. Many survivors still have nightmares and wake up in the middle of the night yelling or in a sweat, pursued by terrifying memories. Telling their story is one way of exorcising the past. Paul Landau's principal motive for confronting the video camera is so as "not to choke myself with the untold story." Externalizing it "dumps it out of my chest."2

There are other aspects that deserve scrutiny here. One of them is our preference for an open-ended and free-flowing interviewing format, so as to assist in the already-mentioned process of opening up on the part of the survivor who is, after all, asked to evoke in words and images aspects of everyday life in a place and time long since gone. The open-ended structure may also enhance the maximum future usefulness of the materials by historians, sociologists and educators alike. It is an aspect which "Living Testimonies" has in common with similar projects of this nature in Canada and the U.S. At this time the central issue is that of securing transmission, of bridging the gap between silence and documentation within the pinching restraints of time. ${ }^{3}$

\section{History}

"Living Testimonies" was founded in 1989. The first five interviews were conducted by Rabbi Ayla Grafstein and Yehudi Lindeman in the Concordia and McGill University studios and led to a half hour video documentary completed in November $1989 .{ }^{4}$

All the interviews are recorded on $3 / 4$ inch studio quality tape. The collection of Sinti (German Gypsy) survivors of the Holocaust is available on $3 / 4$ inch tapes which was copied from the original high eight format. The 20 hours of interviews with the Sinti survivors were recorded in 1991 by Gabrielle Tyrnauer on location in two camping areas in the village of Joditz, near Hof, close to the former East-West German border. The language of the interviews is German. Nearly all of those interviewed are veterans of the Auschwitz Gypsy camp. Some spent time in Jewish camps or ghettos, including the ghet to of Lodz, before being deported to Ausch witz in $1943 .^{5}$

Since the spring of 1990, all in-studio interviews have been recorded at McGill's Instructional Communications Centre (ICC) at 550 Sherbrooke Street West, Montreal, with the generous and expert support of Mario DiPaolo, head of Television and Sound Production, and his competent staff.

By May 1992, "Living Testimonies" had conducted 35 interviews, for a total of about 80 hours. With one exception, all in-studio interviews were conducted in English. Most witness accounts run about two hours, but some are significantly longer, like the early testimony of Harry (or Hershel) Taichman, a survivor of various camps near Lublin who survived because his two sisters pushed him out of the small upper window of the transport train that was carrying them to Treblinka. 


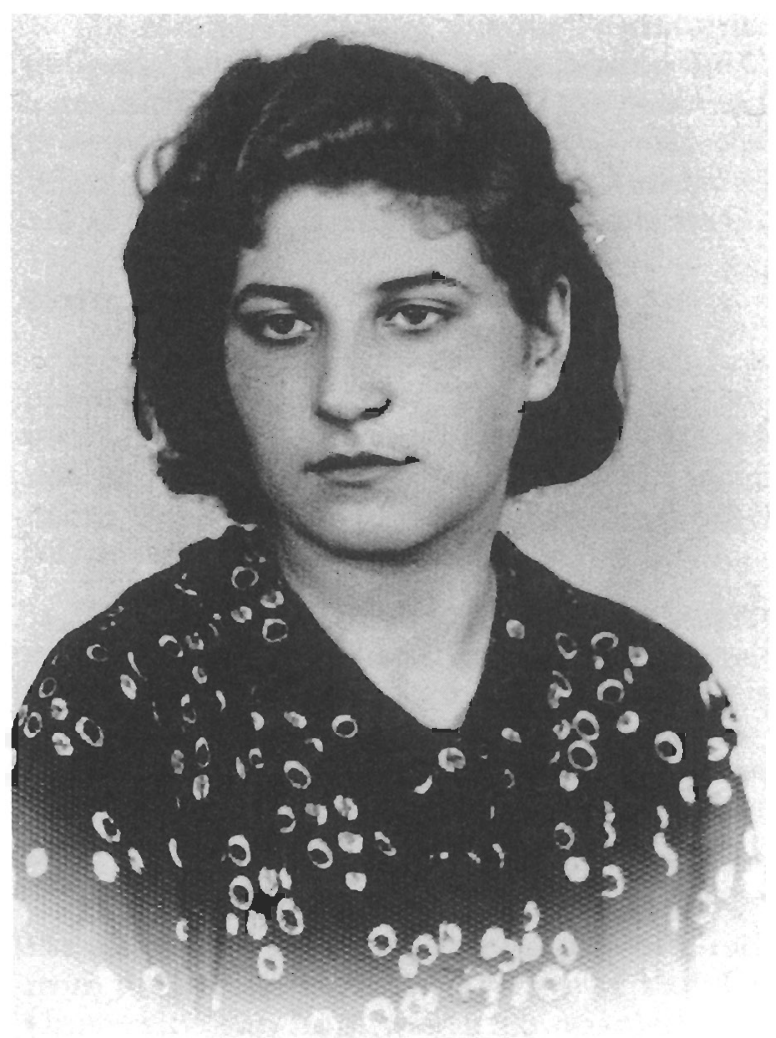

Figure 1. In 1942 the Jewish girl Renata Skotnicka became the Catholic Irena Christina Podbielska. She was able to maintain this new identity with the help of a forged I.D. for which this photograph was taken by an underground photographer.

A typical interview consists of a pre-interview, usually at the survivor's home, followed some days later by the taping session. There is a chronological order to the extent that the interview follows a three-part structure, from the survivor's memories of pre-war life through the war-time experiences of occupation and persecution to, finally, liberation and re-settlement in the new country with its challenges and possibilities for personal and social reintegration.

Any personal materials such as family photographs, camp uniforms or other camp paraphernalia such as badges or, in a rare case, original documents, are photographed and montaged on the video tape itself, whenever possible. These artifacts on tape are meant to complete the collections held privately by individuals as well as the collection of artifacts and memorabilia compiled by Krisha Starker for Montreal's Holocaust Memorial Centre.

\section{Related Collections}

It should perhaps be emphasized that a substantial printed collection of books, articles and bibliographies exists in the McGill Libraries. ${ }^{6}$ Those materials can be searched locally with the help of LC subject heading "Holocaust survivors" on the MUSE automated catalogue which yields 34 categories such as "Personal narratives" and "Bibliographies." Surprisingly, the only bibliography retrieved by this route was that by Leo Eitinger and others. If, leaving the MUSE, one follows the Eitinger bibliography to the Reference shelves, one finds it alongside six other bibliographies on the subject and eight separate volumes in Hebrew.' 


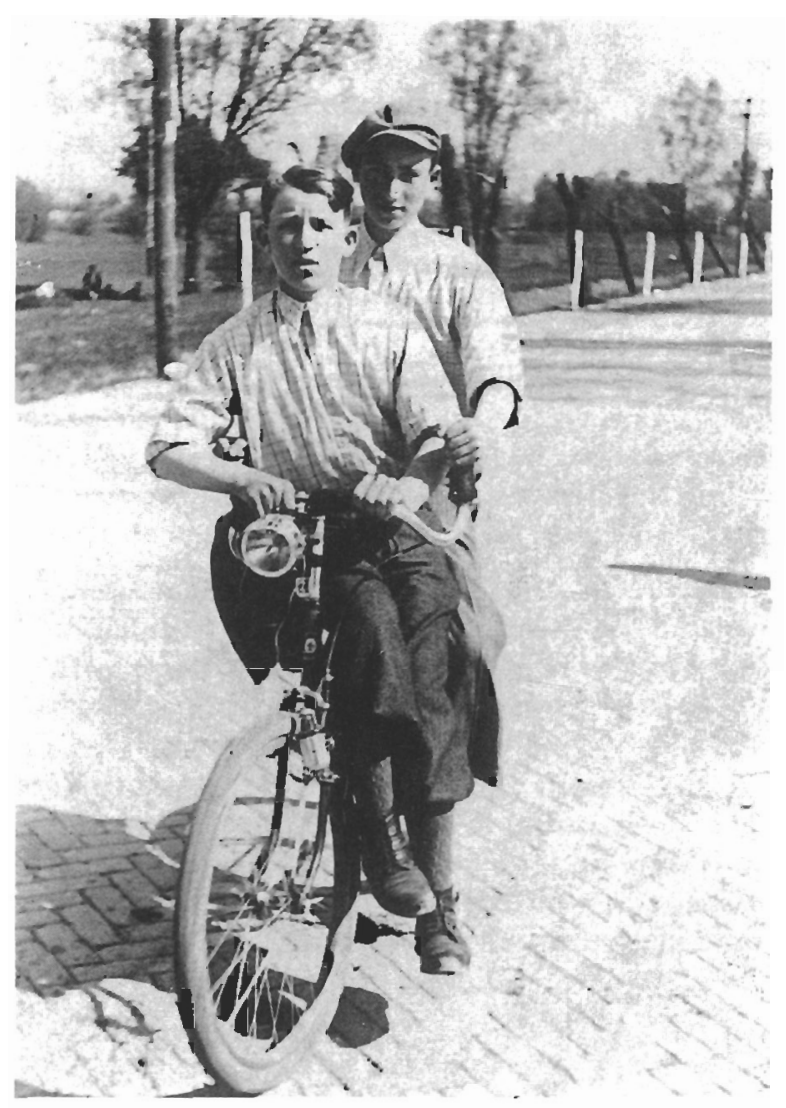

Figure 2. Hershel Taichman and his brother Leibel near Riky, Poland just before World War II.

When contacted, Film Reference Librarian Carol Grossman indicated that the ICC Film Library holds only a handful of relevant films. These include Alain Resnais' Night and Fog (1955) and Stanley Kramer's block-buster Judgement at Nuremburg (1961), as well as Claude Lanzmann's Shoah (1985).

"Living Testimonies" is similar in scope and purpose to projects elsewhere, notably in Canada and the United States. Its most immediate inspiration came from the Holocaust Documentation Project, a collection of studio-quality interviews with about eighty survivors from all over Canada made under the auspices of Canadian Jewish Congress and with the financial support of Canada's Department of Multiculturalism. Those tapes can be viewed upon request at Canadian Jewish Congress in Montreal. ${ }^{8}$

Another stimulating example is Yale University's extensive Fortunoff Video Archive for Holocaust History with which the McGill project is becoming affiliated. In return, Yale will also store copies of all the video interviews recorded at McGill. Among the other video tape collections of note, mention should be made of the Vancouver-based Holocaust Documentation Project directed by Robert Krell at the University of British Columbia and the Toronto-based Holocaust Documentation Project directed by Paula Draper. Other noteworthy collections include the Southeastern Florida Holocaust Memorial Center in Miami and Yad Vashem in Jerusalem. 
The relation between "Living Testimonies" and other oral history projects has not yet been defined. "Living Testimonies" is joining the Canadian Oral History Association and is including a description of its collection in the National Inventory of Oral History Holdings. The Inventory is being compiled right now (1992) with the assistance of the Social Science and Humanities Research Council and the National Archive of Canada and will, for the first time, give researchers access to Oral History collections throughout Canada.

\section{Future}

It is of foremost importance to sort and catalogue the collection and to provide printed synopses of each interview. The anticipated collection will also contain Holocaust-related documentary films (on video) as well as a modest reference library. Also, it is our intention to design a variety of maps to facilitate the location of survivors before and during the Holocaust, using the work of Martin Gibert and others and enlarging some of them for educational purposes.

This reference collection will make it easier to define terms, confirm dates and verify place names. Place names in particular present difficulties as sites are often known under two or three different names, while their spelling is uncertain. Problematic nomenclature especially occurs in border areas. Attention will also be given to the difficulty of transcribing and finding English equivalents for terms and expressions that defy translation. This concerns terms in use during World War II in Polish, Russian, Yiddish and German. Some of this work has already been started with the help of Marcia Goldberg, the Project's tireless research assistant.

So far, funding has been modest. To date, "Living Testimonies" received contributions from the Faculty of Arts and the Faculty of Graduate Studies and Research of McGill University, from the Fortunoff Video Archive of Yale University and through private donations. The Yale University funding was accompanied by matching grants from McGill and Concordia University. We are engaged in a vigorous fund raising effort that will enhance the uses of our project for educational purposes.

Regarding the numbers of planned interviews, there exists something in the nature of a five year plan. The present goal is that, at a rate of 40 interviews a year, approximately 200 new interviews will be produced by the end of 1997.

All tapes will be held in the Department of Rare Books and Special Collections, McGill University Libraries, and are there for storage only. They are the master copies from which copies (usually $1 / 2$ inch VHS) will be made as they are needed. Also, given that the shelf life of the master tapes is a maximum of 50 years, even under optimal conditions, we are already anticipating that the collection may have to be copied onto a less vulnerable medium. One distinct, if as yet distant, possibility is the digital video disc (similar to CD or CD-ROM) which will soon be available at fairly reasonable cost.

While the original master tapes remain in storage and cannot be used or taken out of the Library, VHS copies of the entire collection can be freely viewed at the recently opened new office of "Living Testimonies" at 515 Pine Avenue West, Montreal, Quebec, H2W 1S4. Anyone interested should call (514) 398-8408. It may take about a week to ten days to book an appointment.

\section{Notes}

1. The term "Holocaust" (Hebrew, "Shoah") is used here in its specific meaning of the mass destruction of European Jews by the Nazi German state during World War II. Cf. Israel 
Gutman, editor-in-chief, Encyclopedia of the Holocaust (Jerusalem: Yad Vashem and New York: MacMillan Publishing Company, 1990), 681.

2. From the November 12 and 19, 1991, testimony of Paul Landau, a Frenchman who was born in Warsaw in 1922. Paul was arrested, along with his brother Jacques, and deported to Auschwitz on the eve of the Jewish holiday of Yom Kippur, 1942. Shortly before arrival in Auschwitz, the brothers were taken off the train (later known as Convoy no. 35) at the railway station of Kosel, along with 150 other men. The rest of the convoy of presumably exactly 1000 Jews continued on to Auschwitz where the large majority were gassed instantly. Paul and his brother ended up in a slave labour camp. After the death of his brother, Paul decided to escape, was discovered and, in a bizarre twist of fate, passed through Auschwitz to Oranienburg-Sachsenhausen where he worked as an engraver, forging fake bank notes (mostly British 10 and 20 pound notes) for the Germans before being shipped to Mauthausen and from there to Ebensee where he was liberated by Patton's Third Army. For details of Paul Landau's "Convoy no. 35" see Serge Klarsfeld, Le Mémorial de la déportation des Juifs de France (Paris: 1978).

3. Cf. the emphasis in book after book on the survivor's mission that forces him/her to be a witness, "to tell the story, to bear witness" (Primo Levi) or to "hurl the story [of the Ghetto] in the face of the world." Elie Wiesel, in turn, is caught between his desire to break the silence and his motivation to remain silent, as a gesture of greater loyalty to the unutterable experience itself (see Terrence Des Pres, The Survivor: An Anatomy of Life in the Death Camps [New York: Oxford University Press, 1976], 32, 31 and 35-36, respectively).

4. Yehudi Lindeman (producer and director), Living Testimonies, a video documentary, $3 / 4$ inch, 28 minutes (Montreal, November 1989).

5. For the Gypsies' journey to and final destiny in Auschwitz, see Gabrielle Tyrnauer, Gypsies and the Holocaust: $A$ Bibliography and Introductory Essay, 2nd edition (Montreal: Montreal Institute for Genocide Studies, 1991), xv-xviii.

6. A number of books have recently explored the relation between the survivors' oral testimony and primary documentation as well as more traditional ways of witnessing in diaries and fictional accounts. The most challenging works among them are Lawrence Langer, Holocaust Testimonies: The Ruins of Memory (New Haven: Yale University Press, 1991), Deborah Dwork, Children with a Star (New Haven: Yale University Press, 1991) and Shoshana Felman and Dori Laub, Testimony: Crises of Witnessing in Literature, Psychoanalysis and History (New York: Routledge, 1991). All three works draw extensively on Yale University's Video Archive for Holocaust Testimony.

7. Leo Eitinger and Robert Krell with Miriam Rieck (eds.), The Psychological and Medical Effects of Concentration Camps and Related Persecutions on Survivors of the Holocaust: A Research Bibliography (Vancouver: University of British Columbia Press, 1985). Among other bibliographical tools in the Reference section are Harry James Cargas (ed.), The Holocaust: An Annotated Bibliograpby, 2nd edition (Chicago: American Library Association, 1985) and David Szonyi (ed.), The Holocaust: An Annotated Bibliography and Resource Guide (Hoboken, NJ: KTAV Publishing House, 1985).

8. Montreal cinematographer Alan Handel made a one-hour documentary based on the material in Canadian Jewish Congress' Holocaust Documentation Project called Voices of Survival. It was aired on CBC television in 1989. 